\title{
Performance Evaluation of Common Rail Direct Injection (CRDI) Engine Fuelled with Uppage Oil Methyl Ester (UOME)
}

\author{
D.N. Basavarajappa ${ }^{1}$, N. R. Banapurmath²a*, S.V. Khandal2b, G. Manavendra ${ }^{3}$ \\ ${ }^{1}$ Department of Mechanical Engineering, GMIT, Davangere India. \\ ${ }^{2 a, 2 b}$ Department of Mechanical Engineering, B. V. B. College of Engineering and Technology, Hubli, India. \\ ${ }^{3}$ Department of Mechanical Engineering BIET, Davangere Karnataka, India
}

\begin{abstract}
For economic and social development of any country energy is one of the most essential requirements. Continuously increasing price of crude petroleum fuels in the present days coupled with alarming emissions and stringent emission regulations has led to growing attention towards use of alternative fuels like vegetable oils, alcoholic and gaseous fuels for diesel engine applications. Use of such fuels can ease the burden on the economy by curtailing the fuel imports. Diesel engines are highly efficient and the main problems associated with them are their high smoke and NOx emissions. Hence there is an urgent need to promote the use of alternative fuels in place of high speed diesel (HSD) as substitute. India has a large agriculture base that can be used as a feed stock to obtain newer fuel which is renewable and sustainable. Accordingly Uppage oil methyl ester (UOME) biodiesel was selected as an alternative fuel. Use of biodiesels in diesel engines fitted with mechanical fuel injection systems has limitation on the injector opening pressure (300 bar). CRDI system can overcome this drawback by injecting fuel at very high pressures $(1500-2500$ bar) and is most suitable for biodiesel fuels which are high viscous. This paper presents the performance and emission characteristics of a CRDI diesel engine fuelled with UOME biodiesel at different injection timings and injection pressures. From the experimental evidence it was revealed that UOME biodiesel yielded overall better performance with reduced emissions at retarded injection timing of $-10^{\circ}$ BTDC in CRDI mode of engine operation.
\end{abstract}

Keywords: HOME, HnOME, UOME, CRDI.

Article History: Received November 5, 2014 ; Received in revised form January 20, 2015; Accepted February 10, 2015; Available online

How to Cite This Article: Basavarajappa, D.N. , Banapurmath, N. R., Khandal, S.V., Manavendra, G. (2015) Performance Evaluation of Common Rail Direct Injection (CRDI) Engine Fuelled with Uppage Oil Methyl Ester (UOME). Int. Journal of Renewable Energy Development, 4(1), 1-10. http://dx.doi.org/10.14710/ijred.4.1.1-10

\section{Introduction}

Energy consumption of a country is considered as an index of economic growth and social development (WHO 2006, Mahendra et al. 2010). Besides gross domestic products (GDP) and per capita income, per capita energy consumption is considered as measure of prosperity of a country. The fact that petroleum based fuels will neither be available in sufficient quantities nor at reasonable price in the near future, have drawn interest of researchers in exploring the alternative fuel resources for CI engine applications. Various regulatory bodies have stringent regulations on the engine tailpipe emissions which contribute to global warming and decay of human health which are very serious. The renewable energy scenario with feasibility of using a variety of alternative fuels such as compressed natural gas (CNG), biogas, hydrogen, alcohols, and biodiesel (Kalam 2007, Banapurmath et al. 2009 and 2010, Kjaratad 2010, Planning commission of India 2006) can address the present energy crisis. Two types of oils are available viz. edible and non-edible, edible oils are essential for human consumption and non-edible oils are therefore more suitable for biodiesel production. Many researchers have adopted Mechanical direct injection (MDI) systems in Compression Ignition (CI) engines operated on biodiesel which inject fuel upto

${ }^{*}$ Corresponding author: +919880726748

Email : nr_banapurmath@rediffmail.com 
Citation: Basavarajappa, D.N., Banapurmath, N. R., Khandal, S.V., Manavendra, G. (2015) Performance Evaluation of Common Rail Direct Injection (CRDI) Engine Fuelled with Uppage Oil Methyl Ester (UOME). Int. Journal of Renewable Energy Development, 4(1), 1-10, doi: 10.14710/ijred.4.1.1-10

$\mathrm{P}$ a g e $\mid \mathbf{2}$

400 bar for checking their feasibility derived from different non-edible resources.

The experimental studies on a Direct Injection (DI) CI engine fuelled with Honge biodiesel at injection timings of 19, 23 and 27० BTDC for various loads and at a constant rated speed of 1500 RPM revealed that lower injection timing gave the better performance at high injection pressure (Banapurmath et al. 2008). Nonedible oils like Jatropha, Karanja and Polanga biodiesels showed increased brake specific fuel consumption (BSFC) for all the biodiesel blends with diesel, decreasing trend with speed and reduction in smoke compared to diesel operation which further reduced with blending and operating speeds (Sahoo et al. 2009). Polanga biodiesel gave maximum peak pressure of 6.61 bars higher than that of diesel. The ignition delays (ID) were shorter for biodiesels varying between $6.3^{\circ}$ and $4.2^{\circ}$ crank angle (CA), lower than diesel (Sahoo et al. 2009). The wood pyrolysis oil (WPO) is emulsified with jatropha biodiesel (JOME for CI engine operation and reported that combustion starts compared to diesel (Prakash et al. 2013). The experimental results also clearly indicated that the engine running with biodiesel have slightly higher in-cylinder pressure and HRR than the engine operation with standard diesel and also the BSFC for the engine running with neat biodiesel was higher than the diesel fuelled operation by up to $15 \%$ (Tesfa et al. 2013). Diesel as the base fuel and 30\% of DMF, n-butanol and gasoline as blending fuels with the diesel by volume referred as D30, B30 and G30 when used in multi cylinder reported that the D30 has shown longer ID compared to B30 and G30 because of lower $\mathrm{CN}$ which led to faster burning rate and higher rate of pressure rise. With increase in EGR rate, D30 gave the lowest soot emissions due to extended ID and it has greater effects than fuel oxygen on soot reduction. Using DMF-diesel blends combined with medium EGR may be a better choice for diesel engine to meet future emission regulations along with higher BTE (Chen et al. 2013). The performance and exhaust emissions using refined sunflower oil, cotton seed oil, soybean oil and their methyl esters used as fuels for CI engine showed a little amount of power loss and higher particulate matter (PM) emissions and lower $\mathrm{NO}_{\mathrm{X}}$ emissions (Recep et al. 2001). At higher fuel temperatures with same injection timing and pressure biodiesel emits more Soluble organic fraction (SOF) of PM than gas oil at low engine loads (Nagata 2004). The methyl esters produced slightly higher power than ethyl esters, exhaust emissions of both esters were almost identical (Baiju et al. 2009). Soybean biodiesel indicated faster ignition, lower pre mixed spike and lower peak pressure compare to diesel fuel due to the higher $\mathrm{CN}$ and less heating value of biodiesel when the same mass of fuel injected (Kim et al. 2008). The biodiesel fuels emit substantially lower NO emission specifically when EGR is used [Gerardo et al. 2011, Song 2012).
The use of biodiesel-diesel blends reduced the HC and CO emissions; smoke emissions reduced by $50 \%$ but increased NOx emissions due to higher fuel injection pressure (Kim and Choi 2009, Lee and Park 2002). Increased fuel droplet velocity and decreased droplet size due to increased fuel injection pressure led to better overall mixing of fuel and air, shortened ID, higher HRR, increased in-cylinder temperature (Mueller et al. 2009, Wang et al. 2010). The combustion of the biodiesel starts slightly later than that of the diesel (Ye and Boehman 2010). At high load condition the mixing process of fuel with air is enhanced by higher injection pressure due to high charge temperature and more combustible mixture is formed during ID period (Labecki and Ganippa 2012). Higher injection pressure leads to faster ignition and the peak value of the HRR (Hwang et al. 2014). HRR gradually increased with advanced injection timing regardless of load condition and at high load, the indicated SFC was higher and reached minimum when the injection timing was about 10ªTDC (Carlo et al. 2002). A small difference appears in fuel spray penetration with higher pressures leading to faster penetration and it was noticed that closer to the orifice the higher injection pressure produced droplets of slightly smaller diameter (Benajes et al. 2005). Due to oxygen molecular content and the absence of aromatic and sulphur compounds in biodiesel fuel compared to diesel an improvement in local fuel-oxygen ratio during combustion reduced the smoke opacity in the exhaust (Armas et al. 2006).

The objective of this work mainly focus on the use of non-edible oil (Uppage oil) derived biodiesel and its utilization in CRDI diesel engine applications. Performance and emission characteristics of CRDI engine fuelled with Uppage biodiesel (UOME) were studied to optimize the fuel injection timing for best BTE and then keeping optimum injection timing, injection pressure for best BTE was found. Finally conclusions were drawn from the experimental work on CRDI engine fuelled with UOME.

\section{Material and method}

\subsection{Properties of fuels used}

The fuels used in the study are UOME and compared with the diesel. Transesterification process for the conversion of their methyl ester is explained below.

Amongst the many species which yield oil as a source of energy in the form of bio-fuel, "Garcinia cambogia" (Uppagi) has been found to be one of the most suitable species in India being grown abundantly; it is N2-fixing trace. It is tolerant to water logging, saline and alkaline soils, and is grown in high rainfall region. Garcinia seeds contain 30 to $40 \%$ oil. Garcinia cambogia belongs to the family species. 
Table 1

Fatty acid contribution of Uppage oil sample and its chemical structure

\begin{tabular}{llc} 
structure & & \\
\hline Sl. No. & Fatty acid & Fatty acid contribution (\%) \\
\hline 1 & Palmitic & $3.7-3.9$ \\
2 & Stearic & $2.4-8.9$ \\
3 & Lignoceric & ---- \\
4 & Oleic & $44.5-71.5$ \\
5 & Lignoleic & $1.8-18.3$ \\
6 & Arachidic & $2.2-4.7$ \\
7 & Behenic & ---- \\
8 & Linolenic & ---- \\
9 & Eruceic & ---- \\
\hline
\end{tabular}

The tree grows in forest and is a preferred species for controlling soil erosion and binding soil to roots because of its dense network of lateral roots. The seeds are largely exploited for oil extraction which is well known for its medicinal properties. So far there is no systematic organized collection of seeds. Mixture seeds consist of $95 \%$ kernel and are reported to contain about 27.0 to $40 \%$ oil. The yield of oil is reported to be about 35 to $40 \%$ if mechanical expellers are used for the recovery of oil from the kernels. The crude oil is brown to creamy in color, which deepens on standing. It has a bitter taste and disagreeable odour. Fig. 1 shows the Uppage biomass. Fatty acid contribution of uppage oil sample and its chemical structure is shown in table 1 and the properties of fuels used for the study is shown in Table 2.

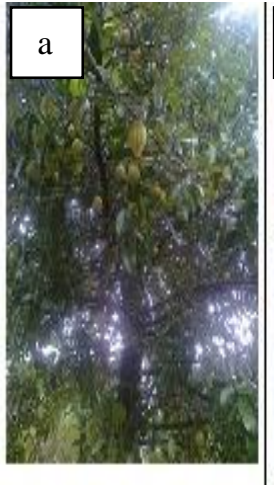

Fig. 1 Uppage biomass(a) Uppage Tree Uppage Seeds

Table 2

Properties of UOME

\begin{tabular}{cllll}
\hline $\begin{array}{c}\text { Sl } \\
\text { No }\end{array}$ & Properties & Diesel & UOME & $\begin{array}{l}\text { Uppage } \\
\text { Oil }\end{array}$ \\
\hline 1 & $\begin{array}{l}\text { Viscosity @ } \\
40^{\circ} \mathrm{C} \text { (cst) }\end{array}$ & $2-5$ & 5.2 & 44.85 \\
2 & Flash point ${ }^{0} \mathrm{C}$ & 75 & 178 & 210 \\
3 & $\begin{array}{l}\text { Calorific Value } \\
\text { in kJ / kg }\end{array}$ & 43000 & 40727 & 38950 \\
4 & Density kg / m ${ }^{3}$ & 840 & 860 & 915 \\
5 & Cetane Number & $45-55$ & 45 & 40 \\
6 & Type of oil & Fossil fuel & Non edible & Non edible \\
\hline
\end{tabular}

\subsection{Transesterification of Uppage oil methyl ester}

The Fig 2 shows the transesterification process in which the upper layer forms the ester and lower layer forms the glycerol. The parameter such as temperature, molar ratio and catalyst concentration that affect the transesterification of Uppage oil were optimized initially. The transesterification set up houses $2 \mathrm{~L}$ Capacity, round bottom flask provided with three necks that was placed in a water container for heating the oil. A heater with a temperature regulator was placed in the round bottom flask. A high speed motor with a magnetic stirrer was used for vigorous mixing of the oil. In the transesterification process triglycerides of Uppage oil reacts with methyl alcohol in the presence of catalyst (NAOH/KOH) to produce a fatty acid ester and glycerol. In this process $1000 \mathrm{~g}$ Uppage oil, $230 \mathrm{~g}$ methanol (MERC brand) and $8 \mathrm{~g}$ sodium hydroxide pellets were placed in the round bottom flask. The contents were heated to $70^{\circ} \mathrm{C}$ and stirred vigorously for one hour to promote ester formation. The mixture was next transferred to a separating funnel and allowed to settle under gravity overnight. The upper layer in the separating funnel consists of ester whist the lower layer is glycerol which was removed .The separated ester with $250 \mathrm{~g}$ hot water and allowed to settle under gravity for 24 hours. Water washing separates residual fatty acids and catalyst and these were removed using a separating funnel. Finally the moisture from the ester was removed by adding silica gel crystals. The properties of Uppage oil and UOME blends were determined using Bureau of Indian Standards (BIS) in the college laboratory.
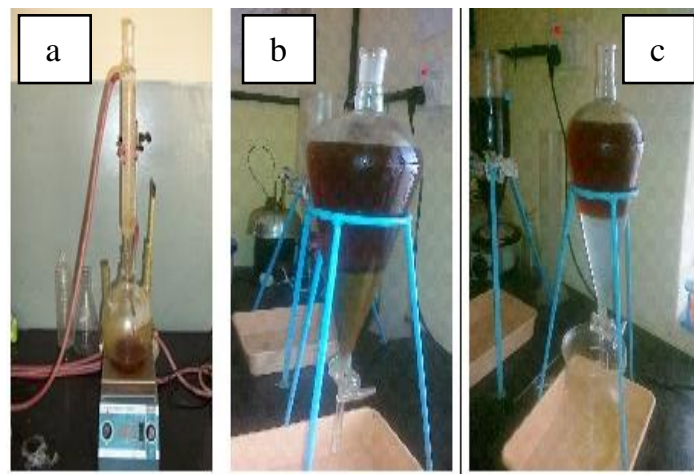

Fig. 2 Biodiesel preparation (a) 3-Neck conical glass bottle for transesterification (b) Separation of Glycerine (c) Washing with hot water

Table 3

Specifications of injector

$\begin{array}{ll}\text { No of holes } & 1 \\ \text { Diameter of the nozzle (mm) } & 0.18 \\ \text { Angle of injector hole } & \text { Parallel to head } \\ \text { Injection pressure } & 1000 \mathrm{bar}\end{array}$

Injection pressure $1000 \mathrm{bar}$ 
Citation: Basavarajappa, D.N., Banapurmath, N. R., Khandal, S.V., Manavendra, G. (2015) Performance Evaluation of Common Rail Direct Injection (CRDI) Engine Fuelled with Uppage Oil Methyl Ester (UOME). Int. Journal of Renewable Energy Development, 4(1), 1-10, doi: 10.14710/ijred.4.1.1-10

\subsection{Experimental methodology}

All experiments were carried out at the rated speed of 1500 RPM at different load conditions. Readings were always taken after the engine attained stability of operation. The temperature of cooling water at exit was maintained at $70^{\circ} \mathrm{C}$. The experiments were conducted using diesel, UOME with three injection timings at the rated speed of $1500 \mathrm{rev} / \mathrm{min}$ under variable load conditions. Further experiments were conducted by varying the injection pressures at the rated speed of $1500 \mathrm{rev} / \mathrm{min}$ at $80 \%$ load conditions in both MDI and EDI mode. Experimental set up is shown in figure 3. Specifications of Injector and CI engine used for the study are shown in Ttables 3 and 4 respectively.

Table 4

CI Engine specifications

\begin{tabular}{cll}
\hline $\begin{array}{c}\text { Sl } \\
\text { No }\end{array}$ & Parameters & Specification \\
\hline 1 & Type of engine & $\begin{array}{l}\text { Kirloskar make Single cylinder four } \\
\text { stroke direct injection diesel engine }\end{array}$ \\
2 & $\begin{array}{l}\text { Nozzle opening } \\
\text { pressure }\end{array}$ & 500 to 205 bar \\
3 & Rated power & $5.2 \mathrm{KW} \mathrm{@1500} \mathrm{RPM}$ \\
4 & Cylinder diameter & $87.5 \mathrm{~mm}$ \\
5 & Stroke length & $110 \mathrm{~mm}$ \\
6 & Compression ratio & $17.5: 1$ \\
\hline
\end{tabular}

\section{Results and discussions}

The existing diesel engine fitted with MDI was suitably modified to operate with CRDI system for supplying fuel at high pressures. With CRDI system, engine started without any difficulty, and it was running smoothly. To determine the suitability of the system, subsequent experiments were conducted with diesel, and UOME and further influence of different injection parameters on the performance and emission characteristics were obtained. The engine tests were conducted at $80 \%$ and $100 \%$ loads at the rated speed of $1500 \mathrm{rpm}$ keeping rail pressure constant at 600 bar by adjusting the pump flow and the pressure regulator valve of the rail. The rail pressures were than varied from 600 to 1000 bar keeping the optimized injection timing. The effect of injection timing and injection pressure on BTE, HC, CO, Smoke and $\mathrm{NO}_{\mathrm{x}}$ are presented in this section. The injection timing is varied from $-25^{\circ} \mathrm{BTDC}$ to $5^{\circ} \mathrm{ATDC}$ in steps of $5^{\circ} \mathrm{TDC}$. Beyond $5^{\circ}$ ATDC considerable knock was observed. It may be noted that the injector used was well matched with the engine and these results represent the variation of parameters and demonstrate the capability of the system.

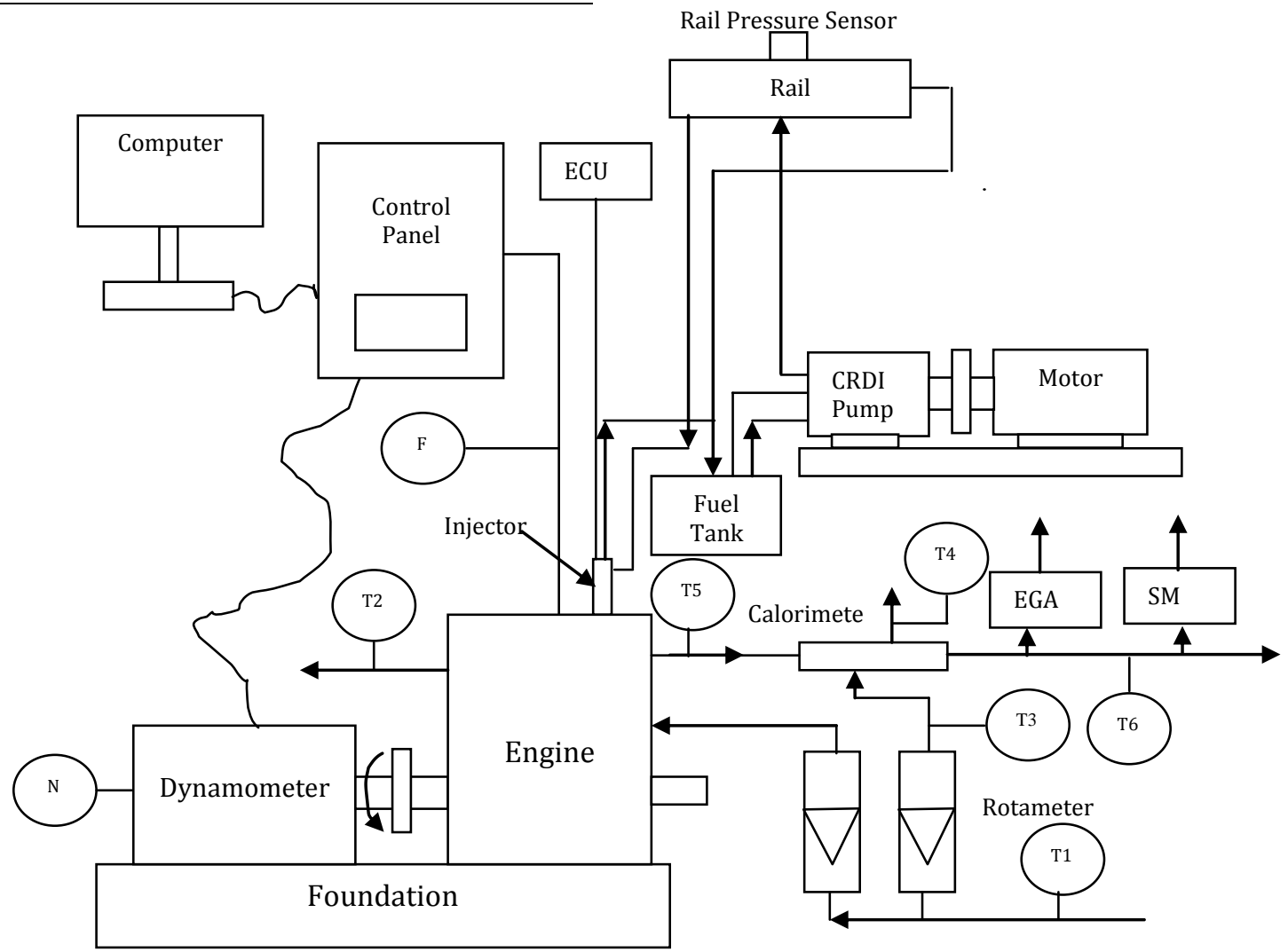

T1, T3 - Inlet Water Temperature, T2 - Outlet Engine Jacket Water Temperature

T4 - Utlet Calorimeter Water Temperature, T5 - Exhaust Gas Temperature before Calorimeter

T6 - Exhaust Gas Temperature after Calorimeter, F - Fluid Flow differential pressure Unit

$\mathrm{N}$ - Speed Encoder, EGA - Exhaust Gas Analyser, SM - Smoke Meter

Figure 3. Experimental set up 


\subsection{Optimization of Injection Timing for UOME.}

\section{Brake thermal efficiency}

Fig 4 shows effect of injection timing on BTE for CRDI system operation with diesel, biodiesel with selected injection timings for $80 \%$ and $100 \%$ loads. For injection timings of -10 to $-5^{\circ}$ the combustion process occurs near to TDC resulting in higher BTE and this could be due to more efficient utilization of fuel resulting in better atomization (Monyem et al. 2001). The maximum BTE for fuels used at fixed injection pressure occurred at injection timing between -10 to $-5^{\circ}$ bTDC at for both higher loads. The advancement or retardation from the optimum value of injection timing could be the reason for deterioration of BTE as shown and the results match those presented in the literature (Senatore et al. 2008). From the Figure, it is observed that higher engine BTE seems to be at SOI between -10 and -5 obTDC and the efficiency decreases with retarded SOI later then 5 obTDC (Ye and Boehman 2011). Engine operation with diesel and biodiesel at $-10^{\circ}$ injection timing performed better than other injection timings. However UOME performed poorly compared to its counterpart diesel due to its higher viscosity and lower calorific value.

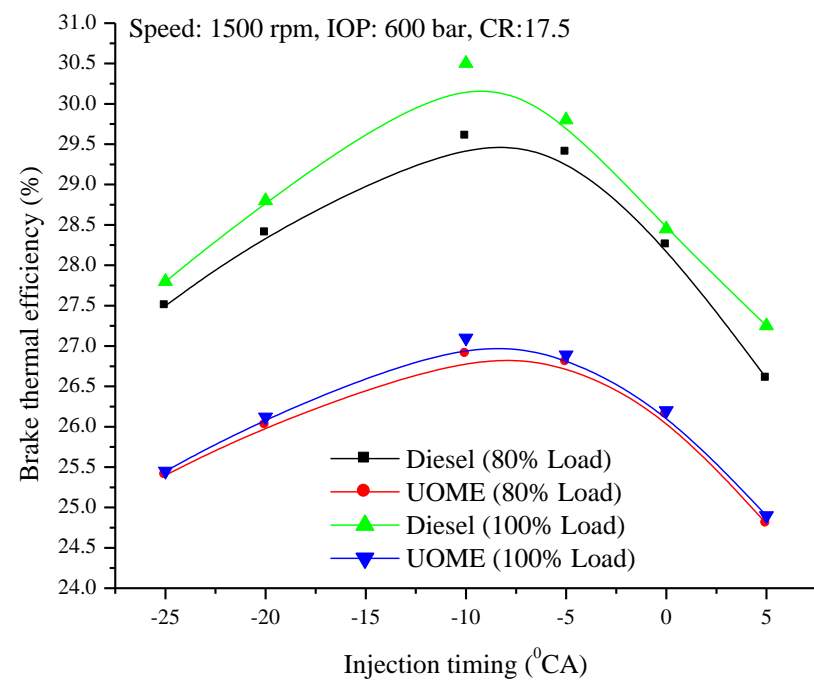

Fig. 4. Effect of injection timings on BTE at $80 \%$ load and $100 \%$ load.

\section{Hydrocarbon emission}

Figure 5 shows the effect of injection timings on HC emissions for diesel and UOME biodiesel when operating the engine at $80 \%$ and $100 \%$ loads. HC emissions of biodiesel are slightly higher than neat diesel engine operation and the reason for this could be the lower BTE obtained with UOME. Biodiesel has higher viscosity resulting in poor atomization at the same injection pressure. The associated wall wetting observed with UOME could also be responsible for the observed trends. HC emissions showed decreasing trend with advancing injection timings of -10 to $-5^{\circ}$
BTDC where fuel conversion efficiency was found to be higher (Carlo et al. 2002).

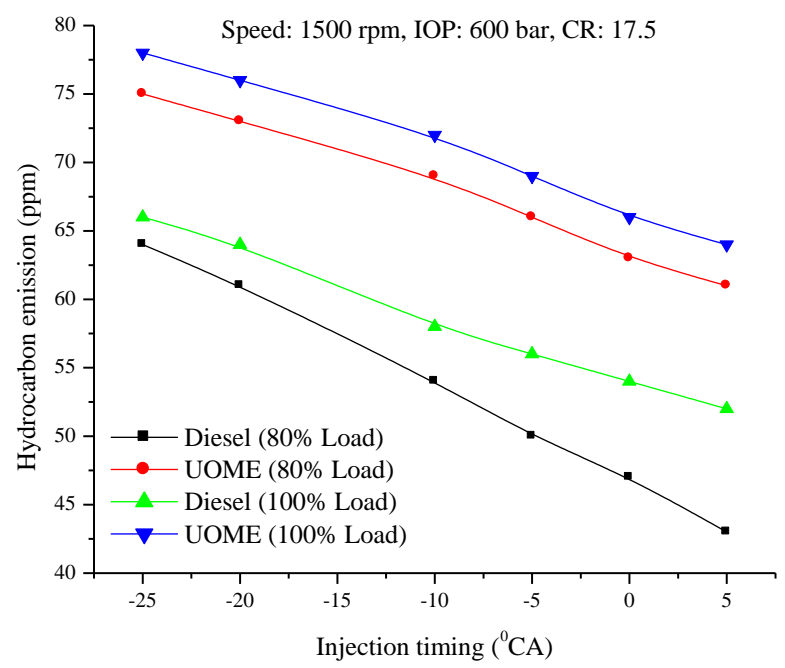

Fig. 5. Effect of injection timings on HC emissions at $80 \%$ load and $100 \%$ load.

\section{Carbon monoxide emission}

Figure 6 shows effect of injection timings on CO emissions for diesel and UOME biodiesel at 80\% and $100 \%$ loads.

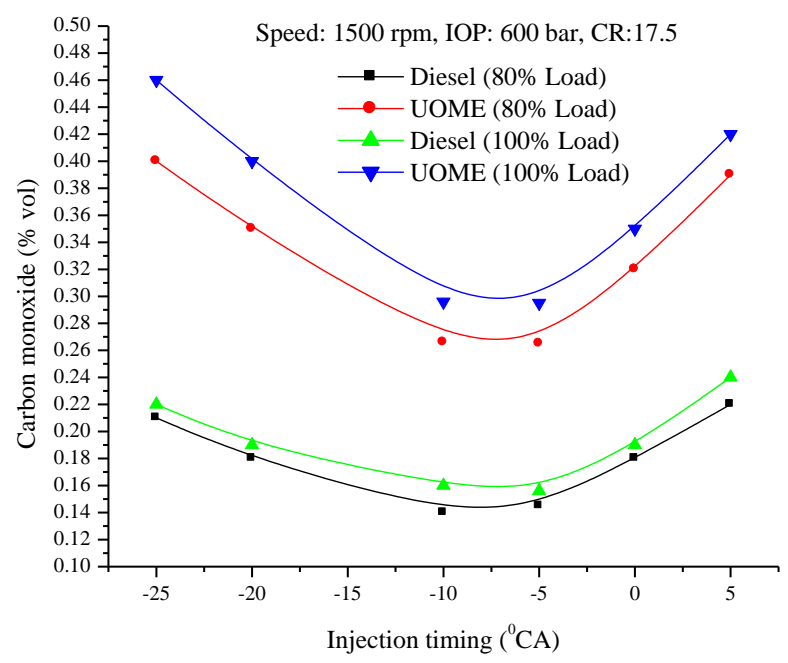

Fig.6. Effect of injection timings on CO emissions at $80 \%$ load and $100 \%$ load.

CO emissions for higher loads of engine operation showed similar trend up to $-5^{\circ} \mathrm{CA}$ TDC as that of $\mathrm{HC}$ emission and showed an increasing trend with retarded injection timing. $\mathrm{CO}$ emissions decrease with advancing injection timing of -10 and $-5^{\circ}$ while it increased with retarded injection timing and this could be due to the 
gas temperature variation observed inside the combustion chamber. Similar results were reported in the literature as well (Carlo et al. 2002). In fact, as the injection timing is retarded, the BTE decreases and for the same power output this increases the amount of fuel delivered. This may be the reason for increase in CO level. At retarded injection timing where the initial pressure and temperature of air is more with higher oxygen content of biodiesels, increases the oxidation process between carbon and oxygen molecules. The lower calorific value and lower volatility of UOME compared to diesel resulted into higher $\mathrm{HC}$ and $\mathrm{CO}$ emissions and this could be due to lower BTE obtained on biodiesel operation.

\section{NO $_{x}$ emission}

Figure 7 shows the effect of injection timings on the emission of nitrogen oxides for CRDI system of operation with diesel and biodiesel at $80 \%$ and $100 \%$ loads. $\mathrm{NO}_{\mathrm{x}}$ emissions were lower for biodiesel operation compared to diesel as they provide lower local peak temperature. $\mathrm{NO}_{\mathrm{x}}$ emission levels increased with advanced injection timings for both biodiesel and diesel. Advancing the fuel injection timing increases the peak in-cylinder pressure due to longer ignition delay resulting in higher peak cylinder temperatures. On the other hand, retarded fuel injection timing causes decrease in ignition delay and in-cylinder gas temperature. Consequently the $\mathrm{NO}_{\mathrm{x}}$ concentration tends to be lesser (Leung et al. 2006). The lower NOx emissions with UOME could be due to its lower premixed combustion and cetane number which lowered peak pressure and lower temperatures prevailing inside the engine cylinder when compared to diesel fuel.

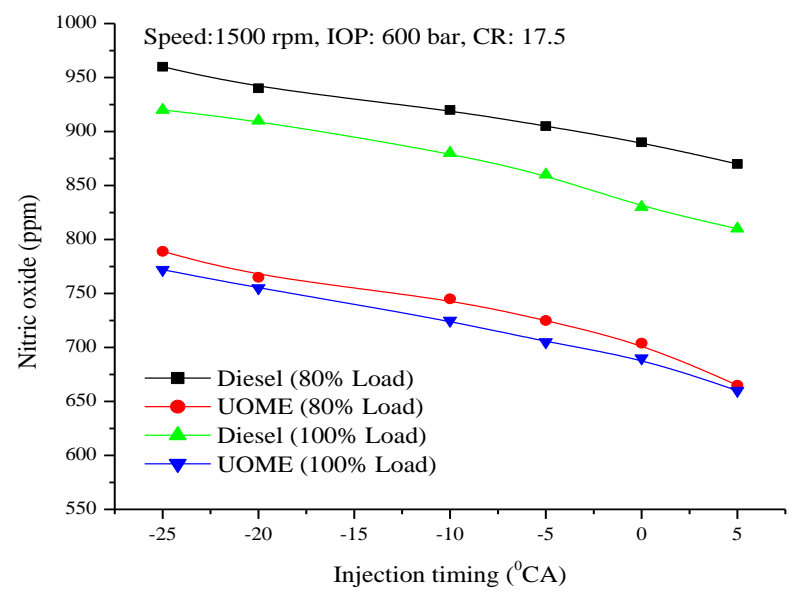

Fig.7. Effect of injection timings on emission of $\mathrm{NO}_{\mathrm{x}}$ at $80 \%$ load and Smoke opacity $100 \%$ load.

Fig 8 shows effect of injection timings on smoke opacity for CRDI system operation with diesel and biodiesel at $80 \%$ and $100 \%$ loads. The smoke emissions of biodiesel were higher than those of the diesel under the same operating conditions. This could be attributed to the presence of free fatty acids (FFA) in the biodiesel leading to poor air-fuel mixture. At an injection pressure of 600 bar the smoke emissions of both the injected fuels decreased with advanced injection timings of -10 and -5 obTDC. This could be due to better combustion on account of more time available for the oxidation process. Smoke emissions of both fuels are increased when the injection timing is retarded due to sluggish and diffusion combustion phase caused by reduced rate fuel-air mixing due to later injection (Sayin et al. 2009). Formation of smoke is basically a process of conversion of molecules of hydrocarbon fuels into soot particles. The lesser smoke opacity of biodiesel at advanced injection timings are mainly due to emission of lower molecules of hydrocarbons and particulate matter.

The advanced injection timing of $-10^{\circ}$ bTDC results into higher BTE but the emissions of smoke, CO and NOx are higher as well. However slightly retarding the timing about -5obTDC lowers the emissions with a small compromise in the BTE. However injection timing of $10^{\circ}$ bTDC was optimized for both diesel and biodiesel operation.

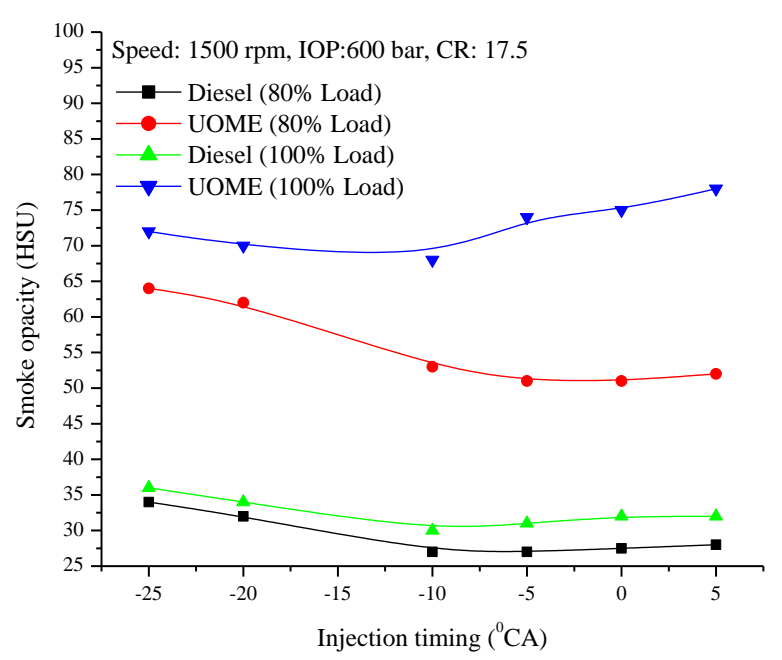

Fig. 8. Effect of injection timings on smoke emission at $80 \%$ load and $100 \%$ load

\subsection{Optimization of Injector Opening Pressure (IOP) for Biodiesel UOME.}

The experiments were conducted to study the influence of injection pressures on CI engine operation using EDI mode. The fuel injection opening pressure was varied while operating the engine at constant speed of 1500 rpm. Injection timing was kept constant at $-10^{0} \mathrm{CA}$.

\section{Brake thermal efficiency}

Figure 9 shows the effect of injector opening pressures on BTE of modified diesel engine fitted with CRDI system using diesel and UOME biodiesel for different 
injection pressures of $600,700,800,900$ and 1000 bar at $80 \%$ and $100 \%$ load respectively. At higher injection pressure the BTE improves due to efficient utilization of fuel associated with better atomization (Bakar et al. 2008). Amongst all the injection pressures tested, the highest BTE was observed with IOP of 900 bar.

For all the IOP tested the BTE values were lower for biodiesel than diesel operation. Lower $\mathrm{CN}$, higher viscosity and lower volatility associated with biodiesel lead to poor atomization and mixture preparation with air during the ignition delay period which results in a later start of combustion for the biodiesel. At 100\% load similar trends were observed with lower values as shown in figure.

As the fuel injection pressure increases from 800 bar to 900 bar the peak of the heat release rate (HRR) as well as the combustion phasing of biodiesel advances due to the reduction of the ignition delay through better air entrainment and fuel-air mixing. Higher injection pressure leads to faster ignition and the peak value of the HRR for biodiesel are lower compared to that of diesel under the reference engine operating condition. When the injection pressure is increased ignition delay decreases due to smaller sauter mean diameter, shorter break up length, higher dispersion and better atomization of injected fuel (Puhan et al. 2009). At high load condition the mixing process of fuel with air is enhanced by higher injection pressure due to higher charge temperature. More combustible mixture is formed during ignition delay period as a result the peak in-cylinder pressure at injection pressure of 900 bar is higher than that of 800 bar injection pressure. Beyond 900 bar IOP there was no significant improvement in BTE. This is probably due to higher injection opening pressure led to wall wetting. Too high IOP (1000bar) will lead to a delayed injection negating the gain in the performance.

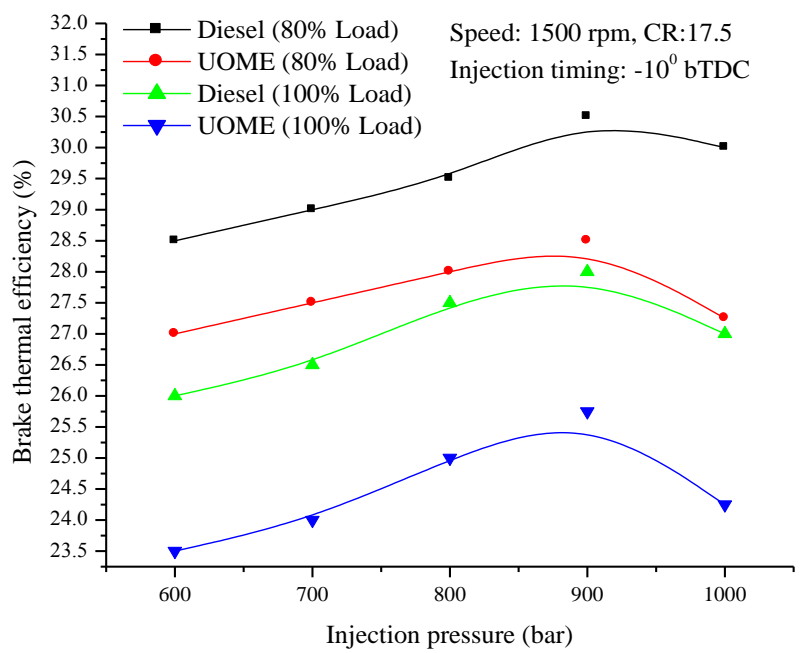

Fig. 9. Effect of IOP on brake thermal efficiency at $80 \%$ load and $100 \%$ load.

\section{Exhaust emissions}

\section{HC and CO emissions}

Figure 10 and 11 shows the effect of injection pressure on $\mathrm{HC}$ and $\mathrm{CO}$ emissions for diesel and biodiesels at $80 \%$ and $100 \%$ loads. At high injection pressure the decreased trend of HC emissions for both fuels were observed and might be due to complete combustion prevailing in the cylinder as the increased injection pressure causes better air-fuel mixing in the combustion chamber. $\mathrm{CO}$ emissions are affected by incylinder gas temperatures and are lower at increased injection pressures. The HC and CO emissions generally decrease with an increase in injection opening pressure. This could be due to the enhanced atomization ensuring stoichiometric fuel-air mixture and better combustion at higher injection pressures. Improved ignition qualities and higher oxygen content of the biodiesel though produce much smaller amount of $\mathrm{HC}$ and $\mathrm{CO}$ emissions they are comparatively higher than diesel and the lowered BTE of UOME are responsible for the trends reported. The highest IOP of 1000 bar leads to an increase in the $\mathrm{HC}$ emission level probably because it leads to a reduction in the BTE.

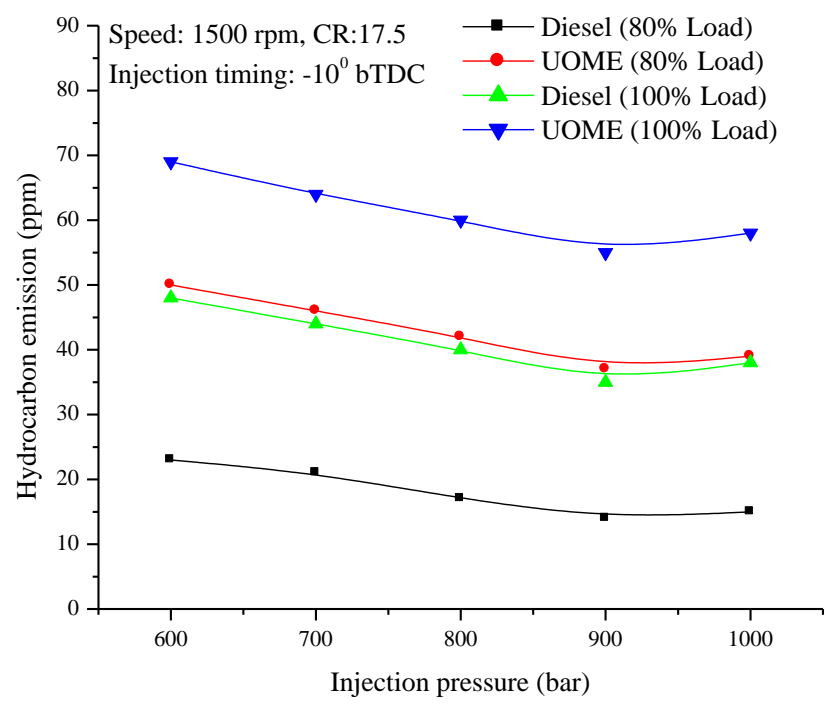

Fig. 10. Effect of IOP on HC emission at $80 \%$ load and $100 \%$ load.

Also a very high IOP will lead to a considerable portion of the combustion occurring in the diffusion phase on account of the small ignition delay. Too high an IOP (1000 bar) will lead to a delayed injection negating the gain due to higher IOP. 


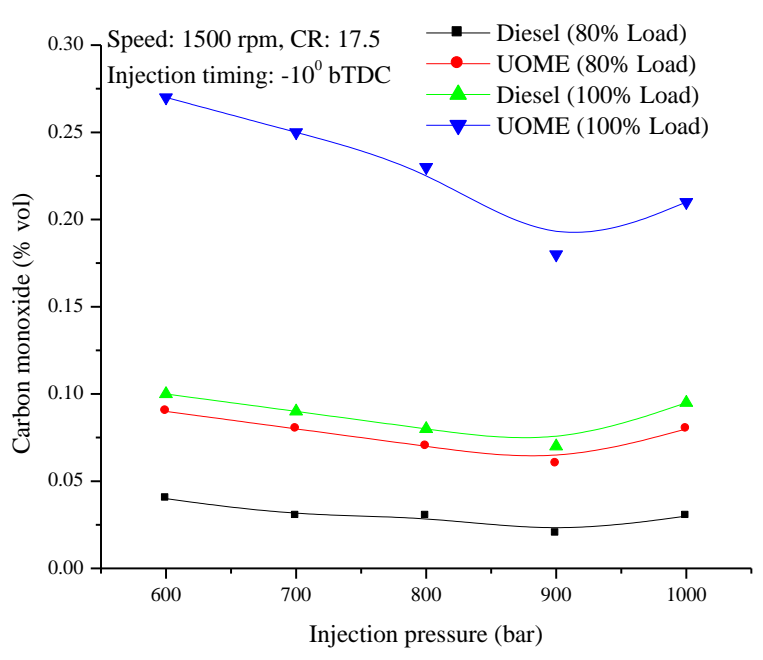

Fig. 11. Effect of IOP on CO emission at $80 \%$ load and $100 \%$ load.

\section{$\mathrm{NO}_{\mathrm{x}}$ emissions}

$\mathrm{NO}_{\mathrm{x}}$ is formed as a result of the oxidation of nitrogen in the air during burning of the air-fuel mixture in the combustion chamber. Its formation is dependent on the duration of the flame temperature in the combustion chamber. The predominant factors involved in this formation process are the air/fuel ratio and the surrounding temperature.

$\mathrm{NO}_{\mathrm{x}}$ emission increased with the increases in IOP due to faster combustion and higher temperatures attained in the cycle as shown in Fig 12 at $80 \%$ and 100\% load.

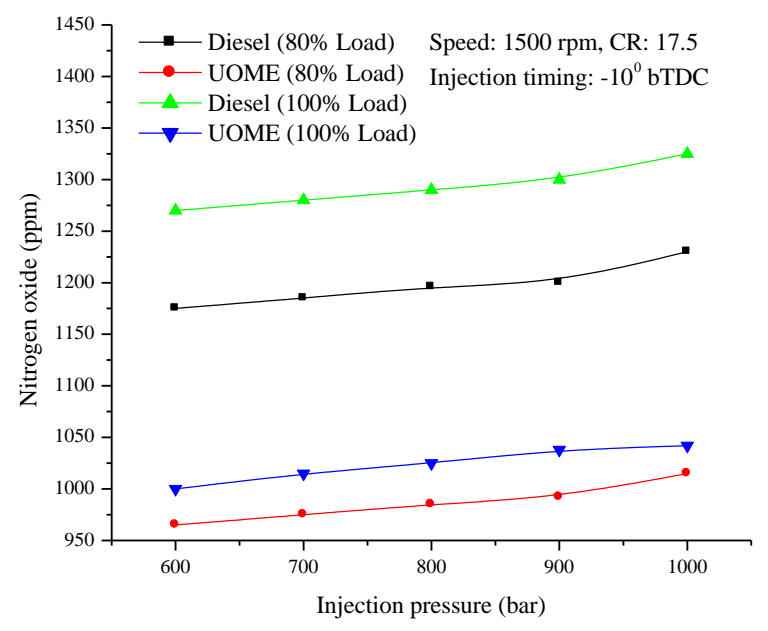

Fig.12. Effect IOP on $\mathrm{NO}_{\mathrm{x}}$ emission at $80 \%$ load and $100 \%$ load.

Higher injection pressure causes the diesel and biodiesel spray to vaporize quickly generating faster combustion rates resulting in higher temperatures. The earlier SOC and higher heat release peak yields longer residence times and/ or higher in-cylinder temperature leading to an increase in $\mathrm{NO}_{\mathrm{x}}$ emissions (Charles et al. 2009). The increased fuel droplet velocity and decreased droplet size (Lee et al. 2005) due to increased fuel injection pressure can lead to better overall mixing between fuel and air and shortened ignition delay. Higher HRR can introduce higher incylinder temperature, yielding increased $\mathrm{NO}_{\mathrm{x}}$ emissions. Biodiesel have reduced premixed combustion and hence show comparatively lower $\mathrm{NO}_{\mathrm{x}}$ compared to diesel. In case of higher IOP, the temperatures rises and consequently more free oxygen atoms of biodiesels combine with nitrogen resulted in increasing the rate of formation of $\mathrm{NO}_{\mathrm{x}}$. UOME biodiesel has lower calorific value and higher viscosity compared to diesel. This leads to lower BTE. Lower adiabatic flame temperature and cetane number resulted into lower NOx emissions with UOME.

\section{Smoke emissions}

Figure 13 show the effect of injection pressures on smoke opacity at $80 \%$ and $100 \%$ loads respectively. Smoke emission reduced with increase in injection pressure and this could be due to enhanced atomization and smaller droplets at an injection pressure of 900 bar. The smaller droplets of fuels can improve mixing with air throughout the combustion chamber resulting in complete combustion. Mixing of air with fuel becomes better through injection period and smoke will be less (Yakup and Duran 2003). Biodiesel has heavier molecular structure because of higher viscosity compared to diesel fuel. This resulted into larger fuel droplets for the same injection pressure. The improper air fuel mixture formed resulted into higher smoke emissions compared to diesel fuel operation. Lowest smoke level is seen with the IOP of 900 bar.

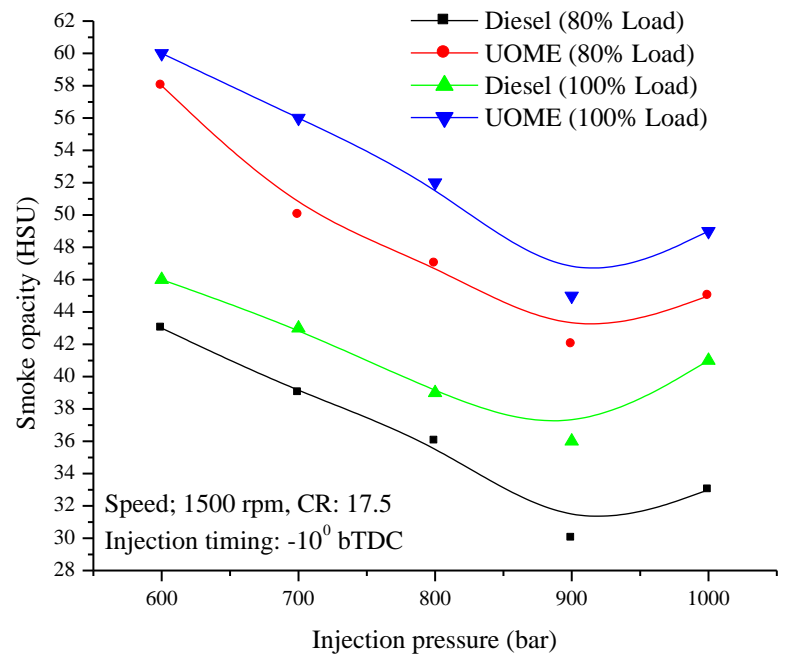

Fig. 13. Effect of IOP on smoke opacity at $80 \%$ load and $100 \%$ load. 


\section{Conclusion}

The existing single cylinder diesel engine with mechanical injection system was suitably modified to operate on CRDI to facilitate varying injection timings and injector opening pressures. From the exhaustive experimentation, the effect of injection timing and IOP on the performance of modified CRDI diesel engine operated with UOME biodiesel the following conclusions were drawn at both $80 \%$ and $100 \%$ loads.

- For biodiesel fuelled engine with CRDI system the BTE showed varying trend with its increased value observed up to $-10^{\circ}$ BTDC and beyond which it reduced. Compared to diesel UOME showed poor performance with reduced BTE.

- HC emissions reduced with retarded injection timing while $\mathrm{CO}$ and smoke emissions increased drastically up to $-10^{\circ}$ BTDC and decreased beyond the said injection timing. However NOx emissions increased with advanced injection timings.

- With increased IOP, BTE increased up to 900 bar and beyond this pressure the BTE reduced due to system limitation.

- HC and CO emissions showed similar trends for both higher loads with reduced values at 900 bar. These emissions increased beyond 900 bar.

- NOx emissions increased with increased IOP.

On the whole it can be concluded that the developed CRDI single cylinder engine operated with UOME biodiesel worked satisfactorily.

\section{References}

1. WHO, 2006, http://www.who.int/ indoorair/publications/ fuel for life / en/index.html.

2. Mahendra Lalwani, Mool Singh. (2010) Conventional and Renewable Energy Scenario of India: Present and Future, Canadian Journal on Electrical and Electronics Engineering, Vol. 1, No. 6, 122-40.

3. Abdul Kalam APJ. (2007). Energy independence and plant and earth. Inaugural address on 94th Indian Science Congress. Annamalai University, Chidambaram, January 5, p. 3.

4. Banapurmath N.R., Tewrai P.G., Vinodkumar V. (2009), combustion and emission characteristics of DI compression ignition engine when operated on Marotti oil methyl ester and its blends Marotti oil methyl ester with diesel, Sustainable Engineering, Vol.2, No.3, $192-200$.

5. Banapurmath, N.R., Tewari, P.G. Performance, combustion, and emissions characteristics of a single-cylinder compression ignition engine operated on ethanol-biodiesel blended fuels, Proc. IMechE, Part A: J. Power and Energy, Vol.224, (2010) 533 - 43.

6. Kjarstad J., Johnsson F. Resources and future supply of oil. Energy Policy, Vol. 37, (2010), 441-64.

7. Planning Commission of India, Report of the Expert Committee on Integrated Energy policy, (2006).

8. Banapurmath N.R., Tewari P.G. and Hosmath R.S. (2008), Combustion and emission characteristics of a direct injection, compression-ignition engine operated on Honge oil, HOME and blends of HOME and diesel. International Journal of Sustainable Engineering. Vol.1, No.2, 80-93.

9. Sahoo P K, Das L M, Babu M K G, Arora P, Singh V P, Kumar N R \&Varyani T S. (2009).Comparative evaluation of performance and emission characteristics of jatropha, karanja and polanga based biodiesel as fuel in a tractor engine. Fuel.
10. Sahoo P.K and Das L.M. (2009) Combustion analysis of Jatropha, Karanja and Polanga based biodiesel as fuel in a diesel engine. Fuel 88, 994-99.

11. Haldar S K, Ghosh B B and Nag A. Studies on the comparison of performance and emission characteristics of a diesel engine using three degummed non edible oils, Biomass and Bioenergy 33 (2009), 1013-18.

12. Abhishek Sharma and S. Murugan. (2013) Investigation on the behavior of a DI diesel engine fuelled with Jatropha Methyl Ester (JME) and Tyre Pyrolysis Oil (TPO) blends. Fuel 108, 699-708.

13. R. Prakash, R.K. Singh, S. Murugan. (2013) Experimental investigation on a diesel engine fueled with bio-oil derived from waste wood-biodiesel emulsions. Energy 55, 610-18.

14. B. Tesfa, R. Mishra, C. Zhang, F. Gu, A.D. Ball. (2013) Combustion and performance characteristics of $\mathrm{CI}$ (compression ignition) engine running with biodiesel. Energy 51, 101-15.

15. Guisheng Chen, YinggangShen, Quanchang Zhang, Mingfa Yao, ZunqingZheng, Haifeng Liu. (2013) Experimental study on combustion and emission characteristics of a diesel engine fueled with 2,5-dimethylfuranediesel, n-butanol-diesel and gasoline diesel blends. Energy 54, 333-42.

16. Altin Recep, Cetinkaya Selim, and Yucesu Huseyin Serdar (2001), The potential of using vegetable oil fuels as fuel for diesel engine, Energy Conversion and Management, 42, 529-538.

17. Koji Nagata, state-of-Art technologies For Diesel Common Rail system. SAE, 2004-28-0068, 442-474.

18. Baiju B., M.K. Naik, L.M. Das, (2009), A comparative evaluation of compression ignition engine characterizes using methyl and ethyl of karanja oil, Renewable Energy 1-6.

19. Myung Yoon Kim, Seung Hyung Yoon, Jin Woo Hwang. (2008), Characteristics of particulate emissions of compression ignition engine fueled with biodiesel derived from soybean. Journal of Engineering for Gas Turbines and Power VOL.130/052805-1.

20. Gerardo Valentino, Luigi Allocca, Stefano Lannuzzi, Alessandro Montanaro. (2011), Biodiesel/Mineral diesel fuel mixtures Spray evolution and engine performance and emissions characterization. Energy 36, 3924-32.

21. Song.H, Tompkins.B.T, Bittle.J.A, Jacobs.T.J. (2012), Comparison of NO emissions and soot constrations from biodiesel-fuelled diesel engine. Fuel 96, 446-53.

22. Hwanam Kim, Byungchul Choi. (2009) The effect of biodiesel and bio ethanol blended diesel fuel on nanoparticles and exhaust emissions from CRDI diesel engine. Renewable Energy 35, 157-63.

23. Carlo N. Grimaldi, LucioPostrioti and Michele Battistoni. Common Rail HSDI engine combustion and emissions with fuel/ Bioderived Fuel Blends. 2002-01-0865,1453-1460

24. Lee C.S., Park S.W., (2002), An experimental and numerical study on fuel atomization characteristics of high pressure diesel injection sprays. Fuel 81, 2417-23.

25. Mueller C. J, Boehman A.L, Martin G. (2009) An experimental investigation of the origin of increased NOx emissions when fueling a heavy duty compression ignition engine with soy biodiesel. SAE paper 2009-01-1792.

26. Wang X., Huang Z., Kuti O.A., Zhang W., Nishida K. (2010) Experimental and analytical study on biodiesel and diesel spray characteristics under ultra-high injection pressure. International Journal of Heat Fluid Flow 31:659-66.

27. Ye P., Boehman A.L., (2010), Investigation of the impact of engine injection strategy on the biodiesel NOx effect with a common-rail turbocharged direct injection diesel engine. Energy Fuels 24:421525.

28. Labecki L., Ganippa L.C. (2012) Effects of injection parameters and EGR on combustion and emission characteristics of rapeseed oil and its blends in diesel engines. Fuel 812417-23.

29. Joonsik Hwang, Donghui Qi, Yongjin Jung, Choongsik Bae. (2014) Effect of injection parameters on the combustion and emission characteristics in a common-rail direct injection diesel engine fueled with waste cooking oil biodiesel. Renewable Energy 63, 917.

30. Benajes J, Payri R, Molina S, Soare V. (2005) Investigation of the influence of injection rate shaping on the spray characteristics in a diesel common rail system equipped with a piston amplifier. Journal of Fluid Engineering 1102/Vol. 127. 
31. Octavia Armas, Juan J Hernandez, Maria D Cardenas,: “Reduction of diesel smoke opacity from vegetable oil methyl ester during transient operation", Fuel, Vol. 85, 2006, pp. 2427 - 2438

32. Monyem A, Gerpen JH, Canakci M. The effect of timing and oxidation on emissions from biodiesel-fueled engines. Trans ASAE $2001 ; 44: 35-42$.

33. Senatore, A. , Cardone, M. Buono D., (2008) Combustion Study of a Common Rail Diesel Engine Optimized to be Fueled with Biodiesel Energy \& Fuels 02/2008; 22(3).

34. Peng Ye, Boehman Andre L., (2011). An investigation of the impact of injection strategy and biodiesel fueling on engine NOx and particulate matter emissions with a common rail turbocharged DI diesel engine Fuel 97, 476-488.

35. Leung D, Luo Y, Chan T. Optimization of exhaust emissions of a diesel engine fuelled with biodiesel. Energy Fuels 2006; 20: $1015 e 23$

36. Sayin C, Ilhan M, Canakci M, Gumus M. (2009) Effect of injection timing on the exhaust emissions of a diesel engine using diesel methanol blends. Renew Energy 34:1261e9.
37. Bakar RA, Ismail S, Ismail AR, Am J. (2008) Fuel injection pressure effect on performance of direct injection diesel engines based on experiment. Am J Appl Sci 5:197e202.

38. Puhan S, Jegan R, Balasubbramanian K, Nagarajan G. (2009) Effect of injection pressure on performance, emission and combustion characteristics of high linolenic linseed oil methyl ester in a DI diesel engine. Renew Energy 34:1227e33.

39. Charles J. Mueller André L. Boehman, and Glen C. Martin. (2009) An Experimental Investigation of the Origin of Increased NOx Emissions When Fueling a Heavy-Duty Compression-Ignition Engine with Soy Biodiesel. SAE 2009-01-1792

40. Chang Sik Lee, Sung Wook Park, and Sang Il Kwon. (2005) An Experimental Study on the Atomization and Combustion Characteristics of Biodiesel-Blended Fuels. Energy Fuels, , 19 (5), pp 2201-2208

41. Yakup I, Duran A. (2003) Effect of fuel cetane number and injection pressure on a DI diesel engine performance and emissions. Energy Convers Manag;44: 389e97. 